\title{
SISTEM INFORMASI PENELUSURAN PERKARA (SIPP): PENELUSURAN ARSIP BERKAS PERKARA DI PENGADILAN AGAMA TEMANGGUNG
}

\author{
Faizatush Sholikhah'1, Dewi Kumalaeni' 2 \\ 1Program Studi Kearsipan, Sekolah Vokasi, Universitas Gadjah Mada \\ faizatush.sholikhah@ugm.ac.id \\ ${ }^{2}$ Alumni Program Studi Kearsipan, Sekolah Vokasi, Universitas Gadjah Mada \\ dewikumalaeni@yahoo.com
}

\begin{abstract}
This paper discusses the implementation of Sistem Informasi Penelusuran Perkara (SIPP) in an effort to facilitate access to the Case Records as a form of court institution accountability. The Case Records considered as the most important part in the process of decision making in the court. However, the problem of loss or inaccuracy in Case Records filing is still occurs. This negligence can harms a person's legal right, such as judicial delays or (even) a wrong decision. Therefore, this study would like to explain the role of electronic systems in facilitating the archive search, both for the community and for the employees of the judiciary. This research uses participative observation method in Pengadilan Agama Temanggung. The results of the discussion are divided into three points. First, SIPP enables quick and easy file access. Second, SIPP can improve the effectiveness of employee performance in Pengadilan Agama Temanggung. Third, SIPP provides protection of legal rights of citizens to obtain justice in the legal process.
\end{abstract}

Keywords: Sistem Informasi Penelusuran Perkara, case records, Pengadilan Agama Temanggung

\section{Intisari}

Tulisan ini mendiskusikan implementasi Sistem Informasi Penelusuran Perkara (SIPP) dalam upaya kemudahan akses Arsip Berkas Perkara sebagai wujud akuntabilitas lembaga pengadilan. Berkas perkara merupakan bagian terpenting dalam pengambilan putusan sidang pengadilan. Namun, permasalahan kehilangan atau ketidaktelitian dalam penyimpanan berkas perkara sering kali masih terjadi. Kelalaian ini berakibat pada kerugian hak legal seseorang dalam bentuk penundaan peradilan atau (bahkan) salah putusan. Oleh sebab itu, kajian ini hendak menjelaskan peran sistem elektronik dalam mempermudah penelusuran arsip, baik bagi masyarakat maupun pegawai lembaga pengadilan. Penelitian ini menggunakan metode observasi partisipatif di Pengadilan Agama Temanggung. Hasil dari pembahasan terbagi menjadi tiga poin. Pertama, SIPP memungkinkan akses berkas perkara dengan cepat dan mudah. Kedua, SIPP dapat meningkatan efektifitas kinerja pegawai di Pengadilan Temanggung. Ketiga, SIPP memberikan perlindungan hak legal warga negara untuk mendapatkan keadilan dalam proses hukum.

Kata kunci: Sistem Informasi Penelusuran Perkara, arsip berkas perkara, Pengadilan Agama Temanggung 


\section{PENDAHULUAN}

Tidak dapat dipungkiri bahwa perkembangan teknologi informasi yang pesat memiliki dampak yang signifikan, termasuk di antaranya adalah bagi kerja pengarsipan. Penggunaan komputer, internet dan berbagai media digital di hampir seluruh kegiatan organisasi menyebabkan terjadinya peralihan dari tradisi arsip paper based menjadi arsip elektronik. Penggunaan email, web, dokumen yang dipindai, hingga penggunaan aplikasi elektronik menjadi realita kegiatan di perkantoran setiap hari. Kemudahan yang ditawarkan oleh sistem elektronik tersebut membuat banyak individu maupun organisasi lantas memilih untuk menyimpan arsip dalam bentuk digital. Namun, penggunaan sistem elektronik untuk kerja administratif membutuhkan upaya yang lebih besar sejak sistem ini mensyaratkan digital file untuk kemudahan pergerakan arsip. Digitalisasi arsip menjadi tahap pertama untuk menyediakan dokumen yang bukan born digital untuk diintegrasikan dalam sistem elektronik.

Canadian Council of Archives mendefinisikan digitalisasi arsip sebagai "transformation of analog information (from whatever from and from whatever support) to digital code" (ICA, www.cdncouncilarchives.ca/

digitarc.html.) Pendapat itu didukung oleh Machmoed Effendhie, dalam Aspek Teoritis dan Legalitas Alih Media Elektronik atau Digitalisasi, yang menyatakan bahwa semua arsip yang telah dialihmediakan/ didigitalisasi ke dalam media elektronik dapat disebut sebagai arsip elektronik (Effendhie). Digitalisasi arsip memiliki berbagai kegunaan dalam kearsipan, namun kajian ini hanya membatasi tujuan digitalisasi arsip penyedia akses secara online.

Dalam perspektif efektivitas organisasi, baik buruknya penataan arsip di suatu organisasi dapat dilihat dari kemudahan dalam pencarian arsipnya (Martono, 1994, p. 47). Pencarian fisik arsip digunakan untuk mengetahui informasi yang terkandung di dalamnya. Tanpa adanya sarana temu kembali atau finding aids yang tepat, dapat berakibat pada lamanya pencarian arsip yang dibutuhkan. Oleh sebab itu, banyak organisasi mulai mengembangkan sistem elektronik untuk mengelola arsip. Salah satu nya adalah aplikasi Sistem Informasi Penelusuran Perkara yang dikembangkan oleh Mahkamah Agung pada tahun 2016. Sistem ini memuat Daftar Arsip Perkara dan dapat digunakan oleh semua pengadilan yang ada di Indonesia.

Daftar Arsip Perkara merupakan inventaris berkas perkara yang dihasilkan oleh kinerja pengadilan. Informasi penting di dalam berkas perkara menyebabkannya rentan hilang atau musnah jika tidak ada pengamanan yang memadai. Dengan pertimbangan sensitifitas informasi, maka kehilangan salah satu berkas dapat menyebabkan penundaan proses pengadilan. Salah satu contoh kasus perkara yang tertunda dikarenakan kuranglengkapannya berkas arsip adalah pengadilan kasus pembunuhan aktivis hak asasi manusia, Munir Said Thalib. Dokumen hasil penyelidikan Tim Pencari Fakta (TPF) dinyatakan hilang beberapa waktu menjelang proses peradilan (Kompas 11 Oktober 2016).

Hilangnya dokumen dalam
persidangan sengketa dari hasil penyelidikan dapat membuat sidang tertunda, kesalahan putusan, sampai diskriminasi terhadap hak orang yang berada di ekonomi lemah (USAID, 2001). Oleh sebab itu, pada pasal 83 UU No. 43 Tahun 2009 telah dijelaskan tentang ketentuan pidana bagi setiap orang yang dengan sengaja tidak menjaga keutuhan, keamanan, dan keselamatan arsip. Hal ini diperkuat dengan penjelasan pasal 87, yaitu:

$\begin{array}{lr}\text { "Setiap orang yang } \\ \text { memperjualbelikan } & \text { atau } \\ \text { menyerahkan arsip yang memiliki } & \text { nilai guna kesejarahan kepada }\end{array}$


pihak lain di luar yang telah
ditentukan sebagaimana
dimaksud dalam Pasal 53 dipidana
dengan pidana penjara paling
lama 10 (sepuluh) tahun dan
denda paling banyak Rp
$500.000 .000,00$ (lima ratus juta
rupiah)."(Undang-Undang
Kearsipan Nomor 43 tahun 2009
Pasal 87)
Resiko kehilangan dokumen menjadi keniscayaan dalam pengelolaan arsip yang volumenya terus meningkat seperti di Lembaga Pengadilan Agama. Proses pembuatan berkas perkara dari mulai pendaftaran hingga penyelesaian masalah di Peradilan menghasilkan arsip pada setiap tahapannya. Kuantitas arsip ini memerlukan manajemen kearsipan yang baik dalam penanganan arsip di Pengadilan. Hilangnya arsip, ketidakakuratan dalam penyimpanannya dapat merugikan orang yang berperkara. Integritas Lembaga Pengadilan juga dapat dilihat dari kelengkapan berkas perkara yang dimiliki. Tanpa manajemen arsip yang baik, sangat dimungkinkan adanya pemusnahan atau pencurian berkas perkara.

Permasalahan yang muncul adalah pendaftar yang berperkara seringkali tidak mengingat nomor perkara mereka ataupun tanggal persidangan sehingga dibutuhkan aplikasi yang dapat memudahkan dan dimanfaatkan untuk mengakses informasi tersebut dengan mudah dan dapat diakses dengan cepat. Tanpa data yang akurat, Pengadilan tidak dapat secara tepat waktu untuk menyelesaikan suatu kasus. Berkas perkara yang ditangani dengan baik akan mengurangi kemungkinan penundaan proses peradilan dan kesalahan pengambilan putusan. Dari penelitian ini diharapkan dapat diketahui bagaimana cara penemuan kembali berkas arsip perkara, efektifitas penggunaan dan manfaat aplikasi SIPP pada penyimpanan dan penemuan kembali arsip berkas perkara di Pengadilan Agama
Temanggung.

\section{METODE}

Metode yang digunakan dalam penelitian ini adalah observasi partisipasi. Obyek penelitian adalah Pengadilan Agama Temanggung. Metode ini memungkinkan untuk melihat secara langsung penggunaan Aplikasi SIPP oleh pegawai di Pengadilan Agama Temanggung dalam penanganan arsip berkas perkara. Observasi dilakukan dengan melihat kinerja pegawai di Pengadilan Agama Temanggung setelah diterapkannya aplikasi SIPP. Data yang diperoleh kemudian dianalisis menggunakan pendekatan kearsipan untuk melihat prosedur penyimpanan dan penemuan kembali dengan menggunakan Aplikasi SIPP. Prosedur penyimpanan yang digunakan mengacu pada Manajemen Kearsipan karya Zulkifli Amsyah yang meliputi kegiatan pemeriksaan, mengindeks, mengkode, dan menyortir, serta meletakkan (Amsyah, 1990, p.51). Sistem penyimpanan dan perlengkapan penyimpanan akan merujuk pada prosedur penyimpanan yang dibuat lebih dahulu. Sistem penyimpanan adalah menyimpan dengan berdasarkan kata tangkap dari dokumen yang dapat berupa angka atau huruf dan disusun dengan urutan tertentu. Adapun perlengkapan penyimpanan (filing supplies) berupa penyekat, map, penunjuk, kata tangkap, dan perlengkapan yang lain (Sugiarto, 2005, p.51-79). SIPP dapat menjadi sarana penyimpanan dan penemuan kembali arsip berkas perkara.

\section{HASIL DAN PEMBAHASAN}

Pengadilan Agama Temanggung merupakan salah satu Peradilan Khusus yang menangani perkara perdata Islam (A. Rasyid, p.6). Pengadilan Agama Temanggung didukung oleh Bidang Kepaniteraan dan Bidang Kesekretariatan. Bidang Kepaniteraan 
mempunyai tugas dan fungsi yang berkaitan dengan perkara-perkara yang diadili oleh Pengadilan Agama Temanggung, sementara Bidang Kesekretariatan merupakan bidang yang mempunyai tugas dan fungsi yang berkaitan dengan masalah fasilitatif instansi seperti masalah keuangan, kepegawaian, persuratan, dan lain sebagainya.

Berkas adalah himpunan arsip yang disusun secara logis dan sistematis menggunakan sistem filing tertentu. Dalam pembentukan berkas sistem pemberkasan digunakan dan disesuaikan berdasarkan jenis, tipe serta kegunaan berkasnya (PT Sigma Cipta Utama, 1998, p.31). Penataan berkas merupakan kegiatan mengatur dan menyusun untuk kepentingan pekerjaan sehingga membentuk berkas dengan tipe dan kegunaan sesuai dengan pekerjaan tersebut (Martono, 1992, p.21). Adapun perkara yang dimaksud disini adalah perkara perdata. Perkara perdata adalah perkara perdata baik yang mengandung sengketa maupun yang tidak mengandung sengketa (Nur Rasyid, 1996, p16). Dari pengertian tersebut dapat disimpulkan bahwa berkas perkara adalah himpunan arsip yang tersusun secara sistematis dan logis yang mengandung sengketa ataupun tidak mengandung sengketa. Bidang Kepaniteraan menangani perkara-perkara yang menjadi kewenangan Pengadilan Agama Temanggung di antaranya adalah perceraian, waris, izin poligami, perbankan syariah, dispensasi kawin, pengangkatan anak, pembatalan perkawinan, dan pengesahan perkawinan. Arsip yang dihasilkan Bidang Kepaniteraan di antaranya seperti Arsip Berkas Perkara, Akta Cerai, Buku Register, Buku Jurnal Keuangan Perkara, dan lain sebagainya.

Dalam mengelola arsip berkas perkara, Pengadilan Agama Temanggung menggunakan beberapa sumber hukum seperti BW (Burgerlike Wetboek) atau Kitab Undang-Undang Hukum Perdata,
Wvk (Wetboek van Koophandel) atau Kitab Undang-Undang Hukum Dagang yang digunakan untuk menyelesaikan sengketa ekonomi syariah dan UndangUndang Nomor 20 Tahun 1947 tentang Peradilan Ulangan. Perundangan ini khusus untuk Jawa Madura, UndangUndang Nomor 1 Tahun 1974 tentang Perkawinan dan Peraturan Pemerintah Nomor 9 Tahun 1975 tentang Pelaksanaan Undang-Undang Nomor 1 Tahun 1974, Undang-Undang Nomor 48 Tahun 2009 tentang Kekuasaan Kehakiman, Undang-Undang Nomor 14 Tahun 1985 Tentang Mahkamah Agung dan diubah dengan Undang-Undang Nomor 5 Tahun 2004 dan UndangUndang Nomor 3 Tahun 2009. Selain itu masih ada Undang-Undang Nomor 7 Tahun 1989 tentang Peradilan Agama yang diubah dengan Undang-Undang Nomor 3 Tahun 2006 dan UndangUndang Nomor 50 Tahun 2009, UU tentang Perbankan Syariah dan segala peraturan yang berkaitan dengan perekonomian syariah, Undang-Undang Nomor 38 Tahun 1999 tentang Pengelolaan Zakat dan Undang-undang Nomor 41 Tahun 2004 tentang Wakaf, Inpres Nomor 1 Tahun 1991 tentang Kompilasi Hukum Islam, Peraturan Mahkamah Agung dan Surat Edaran Mahkamah Agung RI yang berkaitan dengan hukum acara perdata, dan Peraturan/Keputusan Menteri yang terkait seperti Menteri Agama dan Menteri Hukum dan HAM. Pengadilan Agama Temanggung juga menggunakan Yurispudensi Mahkamah Agung dan Doktrin Hukum pendapat ahli hukum dan pendapat ulama yang tersebar dalam berbagai kitab-kitab fiqih.

\section{Jenis Arsip}

Arsip Berkas Perkara terdiri dari dua macam yaitu Arsip Berkas Perkara Gugatan dan Arsip Berkas Perkara Permohonan. Arsip Berkas Perkara Gugatan dibagi menjadi dua yaitu berkas 
Gugatan Cerai Talak dan Cerai Gugat. Cerai talak apabila suami yang mengajukan. Cerai Gugat apabila istri yang mengajukan atau yang menggugat. Arsip Berkas Perkara Pengadilan Agama Temanggung relatif banyak. Berdasarkan hasil data observasi partisipasi total perkara setiap tahunnya lebih dari 1000 perkara. Mulai dari tahun 2012 total perkara sejumlah 1781 perkara. Tahun 2013 total perkara sejumlah 1955 perkara. Tahun 2014 total perkara sejumlah 1860 perkara. Tahun 2015 total perkara sejumlah 1889 perkara. Tahun 2016 total perkara sejumlah 1831 perkara. Dari jumlah tersebut dibedakan antara perkara gugatan dan perkara permohonan seperti yang terlihat pada table berikut:

\begin{tabular}{|c|c|c|}
\hline Tahun & $\begin{array}{c}\text { Perkara } \\
\text { Gugatan }\end{array}$ & $\begin{array}{c}\text { Perkara } \\
\text { Permohonan }\end{array}$ \\
\hline 2012 & 1648 & 133 \\
\hline 2013 & 1727 & 228 \\
\hline 2014 & 1669 & 191 \\
\hline 2015 & 1643 & 246 \\
\hline 2016 & 1658 & 173 \\
\hline
\end{tabular}

Tabel 1. Jumlah Arsip Berkas Perkara Sumber: Buku Daftar Arsip Perkara Pengadilan Agama Temanggung

Sarana simpan yang digunakan oleh Pengadilan Agama Temanggung adalah map Ordner yang disimpan di lemari besi kaca sliding di Ruang Arsip. Arsip berkas perkara dimasukkan ke dalam map Minutasi dan disimpan di Rak Statis atau Rak Besi (Kumalaeni, 2017).

Arsip Berkas Perkara yang ada di Pengadilan Agama Temanggung ditata berdasarkan nomor perkara. Arsip Berkas Perkara kemudian disimpan di dalam box yang masing-masing box terdiri dari 10 (sepuluh) berkas. Arsip Berkas Perkara disimpan di rak statis dengan membedakan berdasarkan tahun perkara. Arsip Berkas Perkara permohonan dan gugatan disimpan secara terpisah.

\section{Aplikasi Sistem Informasi Penelusuran Perkara (SIPP)}

Sebelum menggunakan aplikasi SIPP, Pengadilan Agama Temanggung sudah mempunyai alat atau sarana untuk menemukan kembali arsip berkas perkara dalam bentuk manual yang disebut Daftar Arsip Perkara. Perubahan penggunaan SIPP ini membuat Pengadilan Agama Temanggung menambah finding aids yang bersifat elektronik. Meskipun demikian, temu kembali dalam bentuk manual masih digunakan dalam pencarian arsip. Pengelolaan berkas perkara di Pengadilan Agama Temanggung dikelola oleh Panitera Muda Hukum. Alat penemuan kembali yang ada di Pengadilan Agama Temanggung sudah cukup cepat untuk mencari berkas yang dibutuhkan. Arsip Berkas Perkara dapat ditemukan sekitar kurang lebih 3 menit. Komponen yang ada di dalam Daftar Arsip Perkara meliputi Nomor Urut, Nomor Perkara, Nomor Ruang, Nomor Rak, dan Nomor Tingkat. Nomor tingkat terdiri dari 4 tingkat depan belakang. Penulisan tingkat $1 \mathrm{~A}-4 \mathrm{~A}$ dan $1 \mathrm{~B}-4 \mathrm{~B}$ berada dalam satu rak. Item yang baru di dalam daftar arsip perkara terdapat item Tanggal Masuk Box yang diinput dengan melihat buku minutasi perkara pertahun.

Aplikasi SIPP memungkinkan pencarian arsip berkas perkara secara elektronik. Terdapat 10 menu pada tampilan aplikasi SIPP. Menu-menu yang ditampilkan di halaman utama SIPP meliputi menu home, jurnal perkara, register induk keuangan, perdata, jinayat, laporan, jadwal sidang, pesan, arsip perkara, dan antrian. Menu Arsip Perkara hanya menyediakan satu pilihan yaitu Daftar Arsip Perkara. Aplikasi SIPP ini merupakan aplikasi yang fleksibel karena memungkinkan untuk menambahkan daftar arsip perkara apabila diperlukan. Penambahan arsip berkas perkara dapat dilakukan melalui Menu Tambah Arsip dan ada tabel yang wajib diisi. Tabel 


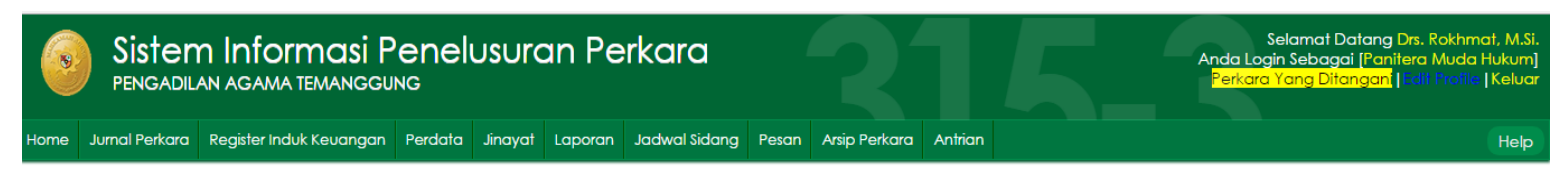

STATISTIK PERKARA DAN REMINDER

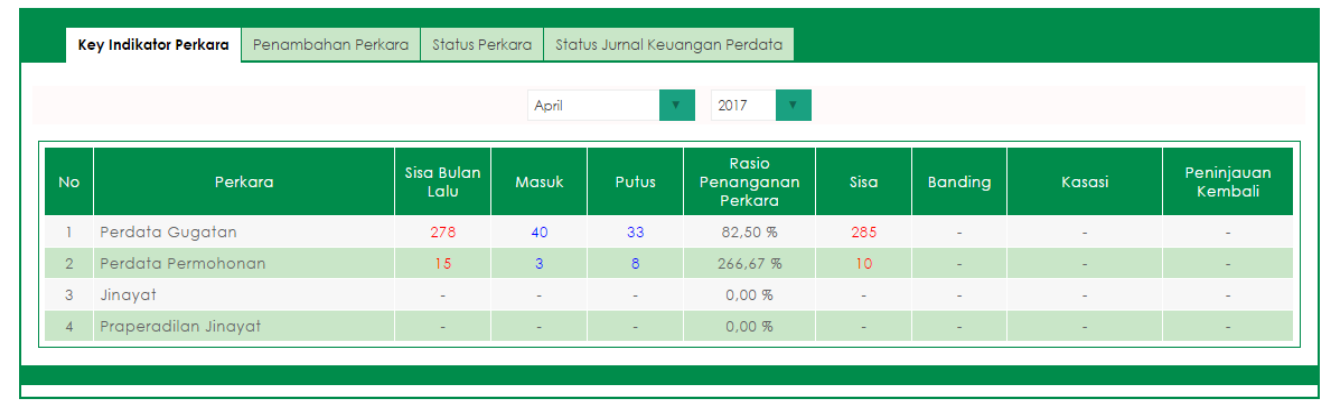

Gambar 1. Aplikasi SIPP Pengadilan Agama Temanggung

Sumber: print screen Fitur Statistik Perkara dan Reminder Aplikasi SIPP Pengadilan Agama Temanggung

tersebut berisi 12 item. 12 item tersebut meliputi Nomor Ruang, Nomor Rak/ Lemari, Nomor Tingkat/Laci, Nomor Boks, Nomor Arsip, Nomor Perkara, Tanggal Masuk, Staff yang menyerahkan berkas, Status, E-Doc Arsip, dan keterangan. Apabila nomor perkara yang akan disimpan sama maka secara otomatis tidak akan bisa disimpan.

Aplikasi SIPP merupakan bagian dari Sistem Manajemen Informasi di Pengadilan. Hal ini juga bagian dari transparansi terhadap proses peradilan bagi masyarakat umum. Masyarakat seringkali mengkhawatirkan adanya kecurangan seperti sogokan agar kasusnya ditutup ataupun diskriminasi kepada masyarakat kecil. Aplikasi elektronik ini memungkinkan pengecekan berkas perkara dan prosesnya menyebabkan tidak hanya kinerja pegawai di pengadilan menjadi lebih efektif dan efisien, melainkan juga meningkatkan kepercayaan masyarakat terhadap proses hukum dan peradilan di Indonesia.

Penelusuran berkas perkara merupakan sistem informasi yang ditujukan untuk mengetahui data dari suatu kasus dan tahapan-tahapan dalam proses pengembangan kasus tersebut sampai hasil akhir kasus. Dalam menangani suatu perkara, penting bagi hakim untuk secara jelas mengetahui perkara yang ditangani. Selain itu, berkas perkara juga membutuhkan pengamanan baik dari akses maupun integritas. Aplikasi SIPP menjadi bagian kegiatan preservasi dan pengamanan arsip berkas perkara.

\section{Akses Perkara}

SIPP memungkinkan akses terhadap berkas arsip perkara. Masyarakat dapat secara langsung mengakses dan mencari subjek perkara. Melalui aplikasi ini, Pengadilan Agama Temanggung dapat menyajikan informasi tentang progres dari kasus atau perkara. Misalnya suatu perkara masih berada di tahap pendaftaran perkara, sidang pertama termasuk lama proses kasus tersebut berjalan. Masyarakat bisa melihat langsung di website dan mencari informasi yang diinginkan. Aplikasi ini sudah membagi berdasarkan klasifikasi perkara namun demikian tetap ada informasi yang tertutup misalnya dengan menyamarkan para pihak tergugat maupun penggugat.

Terdapat beberapa perkara yang bisa diakses melalui SIPP di antaranya 
Perdata Gugatan, Perdata Permohonan, Jinayah, Jadwal Sidang dan Laporan. Masyarakat dapat mengakses data umum, jadwal sidang, biaya perkara dan riwayat perkara. Riwayat perkara yang dapat diakses meliputi pendaftaran perkara sampai dengan penetapan. SIPP juga memungkinkan masyarakat secara langsung melihat data umum pemohon dan putusan penetapan sehingga contoh pada gambar. 2 di bawah.

\section{Transparansi Kinerja Pegawai}

Selain sebagai alat untuk penelusuran berkas bagi kemudahan akses pengguna, Sistem Informasi Penelusuran Perkara (SIPP) juga dapat digunakan sebagai sarana untuk meningkatkan kinerja pegawai di pengadilan. Melalui sistem ini dapat

\begin{tabular}{|c|c|}
\hline Tanggal Pendaftaran & Kamis, 13 Jul. 2017 \\
\hline Klasifikasi Perkara & Dispensasi Kawin \\
\hline Nomor Perkara & 0090/Pdt.P/2017/PA.Tmg \\
\hline Tanggal Surat & Selasa, 11 Jul. 2017 \\
\hline Nomor Surat & 0090/Pdt.P/2017/PA.Tmg \\
\hline Pemohon & $\begin{array}{ll}\text { No } & \text { Nama } \\
1 & \text { Jukaeri bin Sayadi }\end{array}$ \\
\hline \multicolumn{2}{|c|}{ Kuasa Hukum Pemohon } \\
\hline \multicolumn{2}{|l|}{ Termohon } \\
\hline \multicolumn{2}{|c|}{ Kuasa Hukum Termohon } \\
\hline Petitum & $\begin{array}{l}\text { PRIMAIR : } \\
\text { 1. Mengabulkan permohonan Pemohon; } \\
\text { 2. Menetapkan memberikan dispensasi kepada anak Pemohon } \\
\text { yang bernama Adi Nugrahanto Bin Wahyono untuk menikah } \\
\text { dengan Mita Dwi Agustin Binti Agus Purwanto; } \\
\text { 3. Menetapkan besarnya biaya perkara serta pihak yang me- } \\
\text { nanggungnya sebagai akibat dari perkara ini; } \\
\text { SUBSIDAIR: } \\
\text { Atau menjatuhkan putusan lain yang adil dan bijaksana menurut } \\
\text { hukum yang berlaku }\end{array}$ \\
\hline Pihak Dipublikasikan & Ya \\
\hline Prodeo & Tidak \\
\hline
\end{tabular}

Gambar 2. Contoh Arsip Perkara Dispensasi Kawin di PA Temanggung

Sumber: print screen Fitur Statistik Perkara dan Reminder Aplikasi SIPP Pengadilan Agama Temanggung

masyarakat umum dapat mengetahui apakah kasusnya sedang berjalan atau mengalami penundaan dan alasan penundaan sehingga hak legalnya sebagai warga negara bisa terpenuhi, seperti dilihat perkara yang didaftarkan, proses pengurusan perkara, perkara yang belum mendapat ketetapan dari Hakim, perkara yang belum menjalani proses mediasi dan lain sebagainya. Hakim, Panitera Muda 
yang mengurusi data perkara, Panitera Penetapan dan seluruh bagian yang terlibat dalam proses peradilan dapat dilihat kinerjanya dengan indikator waktu
SIPP sehingga publik dapat bersama-sama menjaga peradilan yang memiliki integritas.

\begin{tabular}{|c|c|c|c|c|c|c|}
\hline \multirow{2}{*}{ No } & \multirow{2}{*}{$\begin{array}{c}\text { Tanggal } \\
\text { Transaksi }\end{array}$} & \multirow{2}{*}{ Uraian } & \multicolumn{3}{|c|}{ nominal } & \multirow{2}{*}{ Ket } \\
\hline & & & $\begin{array}{l}\text { Pema- } \\
\text { sukan }\end{array}$ & $\begin{array}{l}\text { Penge- } \\
\text { luaran }\end{array}$ & Sisa & \\
\hline 1 & $\begin{array}{c}\text { Kamis, } 13 \\
\text { Jul. } 2017\end{array}$ & Panjar Biaya Perkara & $\begin{array}{c}\text { Rp. } \\
269.000\end{array}$ & & $\begin{array}{c}\text { Rp. } \\
269.000\end{array}$ & \\
\hline 2 & $\begin{array}{l}\text { Kamis, } 13 \\
\text { Jul. } 2017\end{array}$ & Biaya Pendaftaran/PNBP & & Rp. 30.000 & $\begin{array}{c}\text { Rp. } \\
239.000\end{array}$ & \\
\hline 3 & $\begin{array}{l}\text { Kamis, } 13 \\
\text { Jul. } 2017\end{array}$ & Biaya Pemberkasan/ATK & & Rp. 50.000 & $\begin{array}{c}\text { Rp. } \\
189.000\end{array}$ & \\
\hline & & Total & $\begin{array}{c}\text { Rp. } \\
269.000\end{array}$ & Rp. 80.000 & $\begin{array}{c}\text { Rp. } \\
189.000\end{array}$ & \\
\hline
\end{tabular}

Gambar 3. Contoh Data Biaya di PA Temanggung

Sumber: print screen Fitur Statistik Perkara dan Reminder Aplikasi SIPP Pengadilan Agama Temanggung

proses pengurusan perkara melalui aplikasi tersebut.

Digitalisasi arsip berkas perkara di dalam aplikasi SIPP meminimalisir berkas perkara yang tercecer atau tidak sengaja terselip. Pegawai dapat langsung melakukan upload dalam sistem SIPP dan menyimpan berkas perkaranya di sistem tersebut. Pegawai di pengadilan juga dapat memantau jadwal sidang melalui aplikasi ini. Putusan sidang juga bisa dimasukkan oleh Hakim. Selain Panitera dan Hakim, petugas kasir menginput biaya pendaftaran dan biaya kasus di aplikasi SIPP seperti contoh pada gambar 3 di atas.

SIPP juga meminimalisir adanya upaya penghilangan dokumen atau arsip berkas perkara dikarenakan komunikasi di antara pegawai dilakukan melalui sistem. Data dan informasi perkara hanya diperbolehkan disimpan di aplikasi ini dan pelaporan perkara juga menggunakan aplikasi SIPP. Keterlambatan penanganan perkara dan penyebabnya dapat dilihat dari aplikasi

\section{KESIMPULAN}

Sistem Informasi Penelusuran Perkara (SIPP) merupakan bagian dari Manajemen Sistem Informasi. Sistem manajemen kearsipan di pengadilan ditujukan agar mempunyai temu kembali yang baik. Arsip berkas perkara yang sudah disimpan dapat ditemukan kembali dengan cepat dan mudah, baik arsip dinamis maupun arsip statisnya. Aplikasi SIPP memungkinkan adanya review terhadap berkas suatu perkara sehingga akan diketahui perkembangan suatu kasus. Apabila suatu kasus berjalan tidak sebagaimana seharusnya, maka akan terlihat di sistem ini adanya ketidaklengkapan atau kesalahan prosedur. Dari hasil dan pembahasan di atas, dapat ditarik kesimpulan sebagai berikut: Pertama, SIPP memungkinkan akses berkas perkara dengan cepat dan mudah. Kedua, SIPP meningkatkan efektifitas kinerja pegawai di pengadilan. Ketiga, SIPP turut melindungi hak legal dari warga negara untuk mendapatkan keadilan dalam proses hukum. 


\section{DAFTAR PUSTAKA}

Boedi Martono. 1992. Penataan Berkas Dalam Manajemen Kearsipan. Jakarta: Pustaka Sinar Harapan.

E. Martono. 1994. Rekod Manajemen dan Filing Dalam Praktek Perkantoran Modern. Jakarta: Karya Utama.

International Council on Archives, Digitization and Archives, diakses dari http://

www.cdncouncilarchives.ca/ digitarc.html.

Machmoed Effendhie. "Aspek Teoritis dan Legalitas Alih Media Elektronik atau Digitalisasi", diakses dari http:// arsip.ugm.ac.id/web/

download/1904112051.

M. Nur Rasid. 1996. Hukum Acara Perdata. Jakarta: Sinar Grafika.

Nabilla Tashandra. "Pemerintah diminta beri penjelasan soal Hilangnya Dokumen TPF Kasus Munir" dalam Kompas.com, 55-10-2016, diakses tanggal 31 Agustus 2017.

PT Sigma Cipta Utama. 1998. Terminologi Kearsipan Indonesia. Jakarta: PT Sigma Cipta Utama.

USAID. 2001. Case Tracking and Management Guide. Washington DC: Center for Democracy and Governance Bureau for Global Programs, Field Support and Research US Agency for International Development.

Undang-Undang Kearsipan Nomor 43 tahun 2009.

Zulkifli Amsyah. 1990. Manajemen Kearsipan. Jakarta: PT Gramedia. 